\title{
Bacterial Leaf Scorch, a New Blueberry Disease Caused by Xylella fastidiosa
}

\author{
Chung-Jan Chang ${ }^{1}$ and Ruth Donaldson \\ Department of Plant Pathology, University of Georgia, Griffin Campus, 1109 \\ Experiment Street, Griffin, GA 30223
}

\author{
Phil Brannen \\ Department of Plant Pathology, University of Georgia, 3307 Miller Plant \\ Science Building, Athens, GA 30602
}

\section{Gerard Krewer}

Department of Horticulture, P.O. Box 748, University of Georgia, Horticulture Building, Tifton, GA 31793

\section{Robert Boland \\ University of Georgia, Brantley County Cooperative Extension Service, P.O. Box 275, Nahunta, GA 31553}

Additional index words. rabbiteye blueberry, southern highbush blueberry, Pierce's disease

Abstract. Since 2004, orowers and scientists have observed a disorder described as "yellow twig" or "yellow stem" affecting a major selection of southern highbush blueberry, FL 86-19, in the south Georgia blueberry production region. The initial symptom observed was leaf marginal chlorosis and subsequent necrosis, which eventually progressed throughout the whole leaf resulting in early leaf fall. Thin, yellow twigs or yellow stems became evident on some cultivars. The described symptoms on blueberry were similar to those exhibited on grapes with Pierce's disease and on plum with leaf scald disease. This prompted the enzyme-linked immunosorbent assay (ELISA) tests and isolations of Xylella fastidiosa, which is the causal agent of the previously mentioned grape and plum diseases. Two leaf and two root tissue samples were collected from a diseased FL 86-19 plant for isolation and ELISA testing on 2 Mar. 2006. ELISA results indicated all four tissues tested positive for the bacterial pathogen, $X$. fastidiosa, whereas only the two root tissues provided positive isolations. One leaf and one root tissue sample were later collected from each of five additional diseased plants for isolation and ELISA testing. Both isolation and ELISA testing methods obtained positive results. Cultures were multiplied to inoculate seedlings of three cultivars: 'Southern Belle' (eight plants), 'Premier' (six), and 'Powderblue' (six) on 23 May 2006 and one selection, FL 86-19 (eight), on 31 May 2006. Two FL 86-19 plants started to show symptoms of marginal necrosis 54 days postinoculation, whereas one plant each of 'Southern Belle' and 'Powderblue' started to show symptoms of marginal necrosis 63 days postinoculation and 'Premier' stayed symptomless. All eight culture-inoculated FL 86-19 plants (100\%) showed symptoms 72 days postinoculation, but no symptoms were observed on the control plants. One hundred twenty-six days postinoculation, two 'Powderblue' and four 'Southern Belle' plants showed mild symptoms, whereas all 'Premier' plants were asymptomatic. Positive reisolations of the bacteria from the inoculated symptomatic plants, not from asymptomatic plants, fulfilled Koch's postulates, which confirmed $X$. fastidiosa was the causal bacterium of the new blueberry disorder, the bacterial leaf scorch of blueberry.

Relative to total sales, blueberries are the number one fruit commodity in the state of Georgia, surpassing even peaches. Production is concentrated in the southern coastal flatwoods. Rabbiteye blueberry (Vaccinium virgatum Aiton), a native species, has long been the predominant blueberry species cultivated in Georgia. More recently, however, growers have increased the production of the southern highbush cultivars (V. corymbosum

\footnotetext{
Received for publication 9 Oct. 2008. Accepted for publication 18 Dec. 2008.

${ }^{1}$ To whom reprint requests should be addressed; e-mail cchang@griffin.uga.edu.
}

interspecific hybrids) as a result of a very favorable market window (Scherm and Krewer, 2003). Several new diseases such as necrotic ringspot caused by tobacco ringspot virus and blueberry ringspot virus (Harald Scherm, personal communication) have appeared with the increased production of southern highbush cultivars. Recently, growers and scientists observed a new disorder affecting the southern highbush selection FL 86-19 in the Georgia blueberry production region. An initial symptom was marginal leaf scorch (burn) of the older leaves, similar to that observed with extreme drought or fertilizer salt burn. New developing shoots were usually abnormally thin with a reduced number of flower buds. Leaf drop eventually occurred with young twigs or stems of the southern highbush selection FL 86-19 developing a yellow, "skeleton-like" appearance. At this stage, the root system still appeared healthy, except for the possible loss of fine new roots. Whole plants or individual canes showed symptoms. The plant eventually died after leaf drop, typically during the second year of observation.

The previously mentioned symptoms were inconsistent with any previously reported blueberry disease. It was noticed, however, that the symptoms were similar to diseases caused by $X$. fastidiosa in other plants in south Georgia such as plum leaf scald (Raju et al., 1982; Wells et al., 1987) or pecan bacterial leaf scorch (Sanderlin and Heyderick-Alger, 2000). This observation prompted the initiation of testing to determine whether $X$. fastidiosa could cause these symptoms, and subsequent death, of blueberry plants.

Several reports in the past few years have revealed that $X$. fastidiosa is associated with diseases in a growing number of plant hosts (Almeida et al., 2005; Baumgartner and Warren, 2005; Hernandez-Martinez et al., 2007; Montero-Astua et al., 2008; Myers et al., 2007; Randall et al., 2007). No reports, however, specifically describe the aforementioned blueberry disease. Using a multiprimer polymerase chain reaction (PCR) system, random amplified polymorphic DNA-PCR, and sequence analysis of the 16S-23S rDNA intergenic spacer region, Hernandez-Martinez et al. (2007) reported the phylogenetic relationships of $X$. fastidiosa strains isolated from landscape ornamentals in southern California. They found that strains isolated from daylily, jacaranda, and magnolia clustered with members of $X$. fastidiosa subsp. sandyi and caused oleander leaf scorch but did not cause Pierce's disease on grapes. Strains isolated from Spanish broom and cherry and one strain isolated from western redbud clustered with $X$. fastidiosa subsp. fastidiosa members, whereas strains isolated from purple-leafed plum, olive, peach, plum, sweet gum, maidenhair tree, crape myrtle, and another western redbud strain clustered with members of $X$. fastidiosa subsp. multiplex. All the strains isolated from mulberry and one isolated from heavenly bamboo formed a separate cluster that has yet to be defined as a subspecies. In a separate experiment using nested PCR, Myers et al. (2007) identified the four most abundant sharpshooter leafhoppers in the eastern Piedmont region and the northeastern Coastal Plain in North Carolina: Oncometopia orbona, Graphocephala versuta, Parahlepsius irroratus, and Agolliota constricta. Among them, $O$. orbona, G. versuta, and $P$. irroratus tested positive for the presence of $X$. fastidiosa. Additionally, Myers et al. (2007) observed for the first time in the southeast that $O$. orbona and $G$. versuta were able to transmit $X$. fastidiosa to grapevines.

Almeida et al. (2005) showed that Homalodisca coagulata was able to inoculate $X$. fastidiosa into dormant grapes, although field acquisition experiments did not result in 
transmission. Montero-Astua et al. (2008) reported the finding of $X$. fastidios $a$ in avocado plants in Costa Rica based on the positive results of enzyme-linked immunosorbent assay (ELISA) and PCR, although attempts to cultivate the bacterium in periwinkle wilt (PW) medium (Davis et al., 1981) and buffered charcoal yeast extract medium (Feeley et al., 1979; Raju et al., 1982) were negative.

Furthermore, in their study of the persistence of $X$. fastidiosa in riparian hosts near north California vineyards, Baumgartner and Warren (2005) explained the higher Pierce's disease incidence in Napa vineyards relative to plants in Mendocino. This was based on their finding of higher $X$. fastidiosa populations in California grapes, Himalayan blackberries, and periwinkles in Napa and much less in the same three mentioned plants in Mendocino. Randall et al. (2007) concluded that $X$. fastidiosa is present in New Mexico and that the common landscape ornamental chitalpa is a host for $X$. fastidiosa based on positive results obtained from ELISA, PCR, and cultivation. At the time, direct pathogenicity testing was still in progress.

Based on ELISA and PCR techniques, it is clear that the association of $X$. fastidiosa with new hosts is increasing at a fast pace; however, most of the studies are awaiting fulfillment of Koch's postulates before the relationship between pathogen and host can be asserted. The research presented in this article provides clear evidence that $X$. fastidiosa is the causal bacterium for a new blueberry disease- herein named the bacte- rial leaf scorch of blueberry-by demonstrating the fulfillment of Koch's postulates.

\section{Materials and Methods}

Diseased blueberry tissues. A single diseased blueberry bush of the selection FL 8916 was excavated from a blueberry farm in south Georgia on 2 Feb. 2006. The bush was subsequently stored under cold room conditions $\left(5^{\circ} \mathrm{C}\right)$ - in a plastic trash bag to prevent moisture loss - until attempted detection of $X$. fastidiosa using direct isolation and ELISA tests (Agdia, Inc., Elkhart, IN). From this initial plant, two samples of young stems and two root samples were collected and processed for isolation and ELISA assays on 2 Mar. 2006. The diseased blueberry bush was then moved to a greenhouse and planted in a $30.5-\mathrm{cm}$ diameter pot. This original diseased plant was used to monitor the survival of the bacterium and symptom development on new growth after being stored for $48 \mathrm{~d}$ at $5{ }^{\circ} \mathrm{C}$. Five additional diseased plants and five healthy appearing plants were then collected from south Georgia. On 12 Mar. 2006, five symptomatic stems and five roots were collected from each diseased plant, and five asymptomatic stems were collected from the five healthyappearing plants. These samples were stored at $5{ }^{\circ} \mathrm{C}$ until a second round of attempted isolations and ELISA tests.

Bacterial isolation and enzyme-linked immunosorbent assay. Each sample (1 g root or stem tissue) was surface-sterilized with a
$0.8 \%$ sodium hypochlorite solution for $3 \mathrm{~min}$ followed by three rinses with sterilized water ( $5 \mathrm{~min} /$ rinse). The sterilized tissues were macerated in $3 \mathrm{~mL}$ of $\mathrm{PW}$ broth (Davis et al., 1981) with a sterilized razor blade. The resulting sap suspension was streaked onto PW, CS20 (Chang and Walker, 1988), and XF-26 (Chang and Donaldson, 1993) plates for the direct isolation of $X$. fastidiosa. Streaked plates were sealed in a plastic bag and incubated at $28{ }^{\circ} \mathrm{C}$ for at least 4 weeks and observed on a weekly basis for colony development using a dissecting scope. The remaining sap suspension was mixed with an equal volume of antigen buffer (Agdia, Inc.) in a sterile $5 \mathrm{~mL}$ polystyrene tube $(12 \times 75$ $\mathrm{mm}$ ). This mixture was either immediately used for ELISA testing or frozen for later use. A commercial kit (DAS ELISA for Xylella fastidiosa; Agdia, Inc.) was used for ELISA testing according to the manufacturer's direction. The ELISA reader used for this work was a Labsystems Multiskan RC Version 6.0 (Helsinki, Finland) purchased from Fisher (Pittsburg, PA). The wavelength selected for reading the plates was $620 \mathrm{~nm}$, sufficiently close to the $650 \mathrm{~nm}$ recommended by the Agdia ELISA Kit. Data values for each well were calculated from the raw data by correction relative to a buffer-only well set as zero. Calculated data values are presented in Table 1 and Table 2; those values greater than 0.100 are considered positive (Agdia, Inc.).

Pathogenicity tests of the cultured $X$. fastidiosa. Bacterial cell suspensions were prepared by scraping colonies from five 7 - to

Table 1. The reisolation and enzyme-linked immunosorbent assay (ELISA) results on cultivars Premier, Powderblue, and Southern Belle.

\begin{tabular}{|c|c|c|c|c|c|c|c|c|c|c|c|c|c|}
\hline \multirow{2}{*}{$\frac{\text { Cultivar }}{\text { Premier }}$} & \multicolumn{3}{|c|}{ Date 1: $23 \mathrm{May} / 28$ June $^{\mathrm{z}}$} & \multirow{2}{*}{$\frac{\text { Reisolation }}{0 / 2}$} & \multicolumn{2}{|c|}{ Date 2: 23 May/2 Aug. } & \multirow{2}{*}{$\frac{\text { Reisolation }}{0 / 2}$} & \multicolumn{2}{|c|}{ Date 3: 23 May/7 Sept. } & \multicolumn{3}{|c|}{ Date 4: 23 May/12 Oct. } & \multirow{2}{*}{$\frac{\text { Reisolation }}{0 / 2}$} \\
\hline & \multicolumn{3}{|c|}{ ELISA } & & \multicolumn{2}{|r|}{ ELISA } & & \multicolumn{2}{|c|}{ ELISA } & $\frac{\text { Reisolation }}{0 / 2}$ & \multicolumn{2}{|c|}{ ELISA } & \\
\hline & PW2 & & -0.012 & & & 0.020 & & & -0.011 & & & 0.045 & \\
\hline & S3 & & -0.013 & & & -0.012 & & & 0.001 & & & 0.073 & \\
\hline & $\mathrm{R} 1$ & & -0.006 & & & -0.004 & & & -0.008 & & & 0.042 & \\
\hline & R2 & & -0.011 & & & -0.011 & & & -0.011 & & & 0.048 & \\
\hline blue & PW2 & & -0.012 & & & 0.010 & & & 0.029 & & & -0.001 & \\
\hline & $\mathrm{S} 1$ & $0 / 6$ & -0.009 & $0 / 6$ & $1 / 6$ & 0.032 & $1 / 6$ & $0 / 6$ & 0.020 & $0 / 6$ & $1 / 6$ & $0.153+$ & $0 / 6$ \\
\hline & S2 & & -0.010 & & & $0.154+^{v}$ & + & & -0.020 & & & 0.058 & \\
\hline & S3 & & -0.017 & & & 0.024 & & & -0.005 & & & 0.022 & \\
\hline & R1 & & -0.019 & & & -0.013 & & & 0.042 & & & 0.056 & \\
\hline & R2 & & -0.015 & & & -0.023 & & & 0.035 & & & 0.036 & \\
\hline & R3 & & -0.012 & & & -0.002 & & & 0.011 & & & 0.058 & \\
\hline & S4 & & -0.006 & & & -0.016 & & & -0.030 & & & -0.001 & \\
\hline & R1 & & -0.012 & & & -0.006 & & & -0.029 & & & $0.113+$ & \\
\hline & R2 & & -0.012 & & & -0.013 & + & & -0.036 & & & $0.223+$ & \\
\hline & R3 & & -0.003 & & & $0.122+$ & + & & -0.032 & & & 0.012 & \\
\hline & $\mathrm{R} 4$ & & -0.019 & & & -0.004 & & & -0.028 & & & 0.011 & \\
\hline
\end{tabular}

${ }^{\mathrm{z}}$ Inocualtion date/reisolation and ELISA testing date.

${ }^{y}$ Blueberry plants received inoculation with periwinkle wilt broth (PW), strain of cell suspension originally isolated from diseased stem tissues (S), and that from diseased root tissues (R).

${ }^{x}$ Total number that gave positive ELISA or reisolation/total number of inoculated plants.

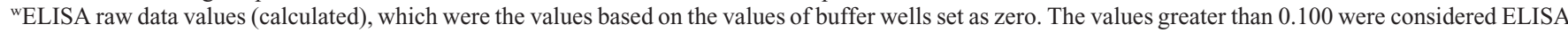
positives.

v"+" represented positive result either based on ELISA or reisolation of the tissues collected from that particular blueberry plant. 
Table 2. The reisolation and enzyme-linked immunosorbent assay (ELISA) results on selection FL 89-16.

\begin{tabular}{|c|c|c|c|c|c|c|c|c|c|c|c|c|c|}
\hline \multirow{2}{*}{ Selection } & \multicolumn{3}{|c|}{ Date 1: $31 \mathrm{May} / 11 \mathrm{July}^{z}$} & \multirow[b]{2}{*}{ Reisolation } & \multicolumn{2}{|c|}{ Date 2: $31 \mathrm{May} / 2 \mathrm{Aug}}$. & \multirow[b]{2}{*}{ Reisolation } & \multicolumn{2}{|c|}{ Date 3: 31 May/7 Sept. } & \multicolumn{3}{|c|}{ Date 4: $31 \mathrm{May} / 21 \mathrm{Sept}}$. & \multirow[b]{2}{*}{ Reisolation } \\
\hline & & \multicolumn{2}{|c|}{ ELISA } & & & ELISA & & & ELISA & Reisolation & & ELISA & \\
\hline$\overline{\text { FL 86-19 }}$ & $\mathrm{PW} 1^{\mathrm{y}}$ & $0 / 4^{x}$ & $0.000^{\mathrm{w}}$ & $0 / 4$ & $0 / 4$ & 0.019 & $0 / 4$ & $0 / 4$ & -0.030 & $0 / 4$ & $0 / 4$ & -0.001 & $0 / 4$ \\
\hline & PW2 & & -0.005 & & & 0.002 & & & -0.028 & & & 0.002 & \\
\hline & PW3 & & 0.006 & & & -0.002 & & & -0.024 & & & 0.023 & \\
\hline & PW4 & & 0.014 & & & & & & -0.020 & & & -0.005 & \\
\hline & $\mathrm{S} 1$ & $4 / 8$ & $0.303+{ }^{\mathrm{v}}$ & $7 / 8+$ & $5 / 8$ & $0.325+$ & $6 / 8+$ & $5 / 8$ & $0.463+$ & $5 / 8+$ & $7 / 8$ & $0.532+$ & $6 / 8+$ \\
\hline & $\mathrm{S} 2$ & & -0.003 & + & & $0.581+$ & + & & $0.630+$ & + & & $0.300+$ & + \\
\hline & S3 & & -0.004 & & & -0.013 & & & 0.004 & & & $0.291+$ & + \\
\hline & $\mathrm{S} 4$ & & 0.008 & + & & 0.023 & + & & -0.031 & & & $0.761+$ & + \\
\hline & R1 & & 0.055 & + & & 0.004 & & & -0.018 & & & $0.721+$ & + \\
\hline & $\mathrm{R} 2$ & & $0.130+$ & + & & $0.262+$ & + & & $0.131+$ & + & & -0.003 & \\
\hline & R3 & & $0.174+$ & + & & $0.213+$ & + & & $0.308+$ & + & & $0.220+$ & \\
\hline & $\mathrm{R} 4$ & & $0.172+$ & + & & $0.571+$ & + & & $0.521+$ & + & & $0.603+$ & + \\
\hline
\end{tabular}

${ }^{\mathrm{z}}$ Inocualtion date/reisolation and ELISA testing date.

${ }^{\mathrm{y}}$ Blueberry plants received inoculation with periwinkle wilt broth $(\mathrm{PW})$, strain of cell suspension originally isolated from diseased stem tissues (S), and that from diseased root tissues $(\mathrm{R})$.

${ }^{x}$ Total number that gave positive ELISA or reisolation/total number of inoculated plants.

${ }^{w}$ ELISA raw data values (calculated), which were the values based on the values of buffer wells set as zero. The values greater than 0.100 were considered ELISA positives.

v" + " represented positive result either based on ELISA or reisolation of the tissues collected from that particular blueberry plant.

10-d-old PW agar plates into $5 \mathrm{~mL} \mathrm{PW}$ broth. The concentration of the cell suspensions was determined by a serial of 10 -fold dilutions to $10^{-9}$ in PW broth. Diluted cultures were incubated at $28{ }^{\circ} \mathrm{C}$ for at least 4 weeks before the reading of the colorchanging units (CCUs) was concluded. The $\mathrm{CCU}$ was used for the measurement of Spiroplasma citri cell populations in the pistil, sepal, corolla tube, stem, and petals of infected periwinkles (Chang and Zheng, 1999). The color of fresh PW broth medium with phenol red is yellowish at a $\mathrm{pH}$ of 6.7. $\mathrm{X}$. fastidiosa blueberry strains change the $\mathrm{pH}$ of the medium from acidic to basic during growth; this corresponds with a change in the color of the medium from yellow to red or pink when growth reaches the exponential or stationary phase, respectively. Thus, CCUs are useful for a close determination of the concentration of cell suspensions. After incubation at $28{ }^{\circ} \mathrm{C}$ for 4 weeks, the concentrations of cell suspensions for stem and root isolates used for 23 May and 31 May inoculations were $10^{7} \mathrm{CCUs} / \mathrm{mL}$ and $10^{8} \mathrm{CCUs} /$ $\mathrm{mL}$, respectively.

For each inoculation, a cell suspension drop was placed on stems of healthy blueberry plants near the soil line; this was followed by pricking the stems through the cell suspension a few times with a syringe needle until the suspension was absorbed into the xylem. The inoculation sites were marked with sticky tape. All plants were kept in the greenhouse and fertilized monthly with Peters 10-10-10. Symptom development was closely observed and recorded on a weekly basis.

Pathogenicity tests were carried out on two different dates, 23 May 2006 and 31 May 2006. Eight 'Premier', eight 'Powderblue', and 10 'Southern Belle' plants grown in 15.2$\mathrm{cm}$ diameter pots were used for inoculation on 23 May, whereas 12 FL 86-19 were used for inoculation on 31 May. For the first three cultivars, two plants of each cultivar were mechanically inoculated with PW broth as controls, whereas the rest were mechanically inoculated with bacterial cell suspensions (half originally isolated from stems and half originally isolated from roots). Of the $12 \mathrm{FL}$ 86-19 plants, four were mechanically inoculated with PW broth; four were mechanically inoculated with cell suspension of stem origin, and four with that of root origin.

Reisolation of X. fastidiosa from inoculated plants. The protocols for isolations and ELISA tests for $X$. fastidiosa from inoculated plants were similar to those described previously, except the ratio of 1:3 (grams of tissue to milliliters of PW broth medium) was applied when sample weights were less than $1 \mathrm{~g}$. Several isolations and ELISA tests were performed throughout the course of the study. Thirty-seven d postinoculation, leaves 1, 3, and 5 above the inoculation point were collected from each plant of the three cultivars (Premier, Powderblue, and Southern Belle). Leaves from the initial field-diseased blueberry bush were also collected for isolation and ELISA tests. Forty-one d postinoculation, leaves 1,3 , and 5 above the inoculation point of the FL 86-19 plants were collected for isolation and ELISA tests. Sixty-three d postinoculation, leaves 2,4 , and 6 above the inoculation site were collected from FL 8619 plants; $71 \mathrm{~d}$ postinoculation, leaves in the same position were collected from the three other cultivars for isolation and ELISA tests. Ninety-nine d postinoculation, leaves 7,8 , and 9 above the inoculation site were collected from FL 86-19 plants and at $107 \mathrm{~d}$, leaves of the same position were collected from the other three cultivars for isolation and ELISA. At $113 \mathrm{~d}$ postinoculation, leaves from selection FL 86-19 were collected again for isolation and ELISA. At $142 \mathrm{~d}$ postinoculation, leaves from cultivars Premier, Powderblue, and Southern Belle were once more collected for isolation and ELISA.

\section{Results}

Isolation and enzyme-linked immunosorbent assay results. All were positive by ELISA, but isolations were only successful from roots in the direct isolation and ELISA test from stem and root tissues of the original diseased blueberry plant. Five stem and root samples from five additional symptomatic plants also gave positive results in direct isolations and ELISA tests. Five stem samples taken from the five asymptomatic plants gave negative results for both isolation and ELISA. These results provide a strong association of $X$. fastidiosa to the leafscorched blueberry plants. Colony development of the blueberry strains was relatively slow, taking 10 to $14 \mathrm{~d}$ to become visible (Fig. 1A). The colonies were opalescent white and reached 0.03 to $0.07 \mathrm{~mm}$ in diameter in 2 weeks.

Results of pathogenicity tests. For cultivars Premier, Powderblue, and Southern Belle, there was not a distinct symptom development pattern or progression throughout the course of the study. No symptoms were observed on 'Premier'; slight scorch symptoms were observed on one 'Powderblue' (Fig. 1B) plant when inoculated with a stem isolate and two 'Southern Belle' plants when using a stem isolate (Fig. 1C) or a root isolate. For these plants, marginal necrosis and leaf discoloration (turning yellow or pink/red) occurred only to those leaves near the inoculation sites at $125 \mathrm{~d}$ postinoculation. There was no evidence of symptoms developing further in 'Powderblue' or 'Southern Belle' plants, even at 14 months after the initial observation. The findings for selection FL 86-19, however, were completely different. The first marginal necrosis symptoms (of leaves) were observed on a root isolate R1inoculated FL 86-19 plant at 54 d postinoculation (Fig. 2A) and a stem isolate $\mathrm{S} 1$ inoculated plant at $61 \mathrm{~d}$ postinoculation (Fig. 2B). Twelve d later, the previously mentioned FL 86-19 plant (Fig. 2C) showed much degenerated and discolored leaves. Necrotic and discolored leaves continued to appear on the younger leaves along the branch (Fig. 2D). Three months after inoculation, symptoms began to develop on noninoculated branches (Fig. 3A). One hundred ninety $\mathrm{d}$ postinoculation, yellow stems, along with severe necrotic and degenerated symptoms, were observed (Fig. 3B). 

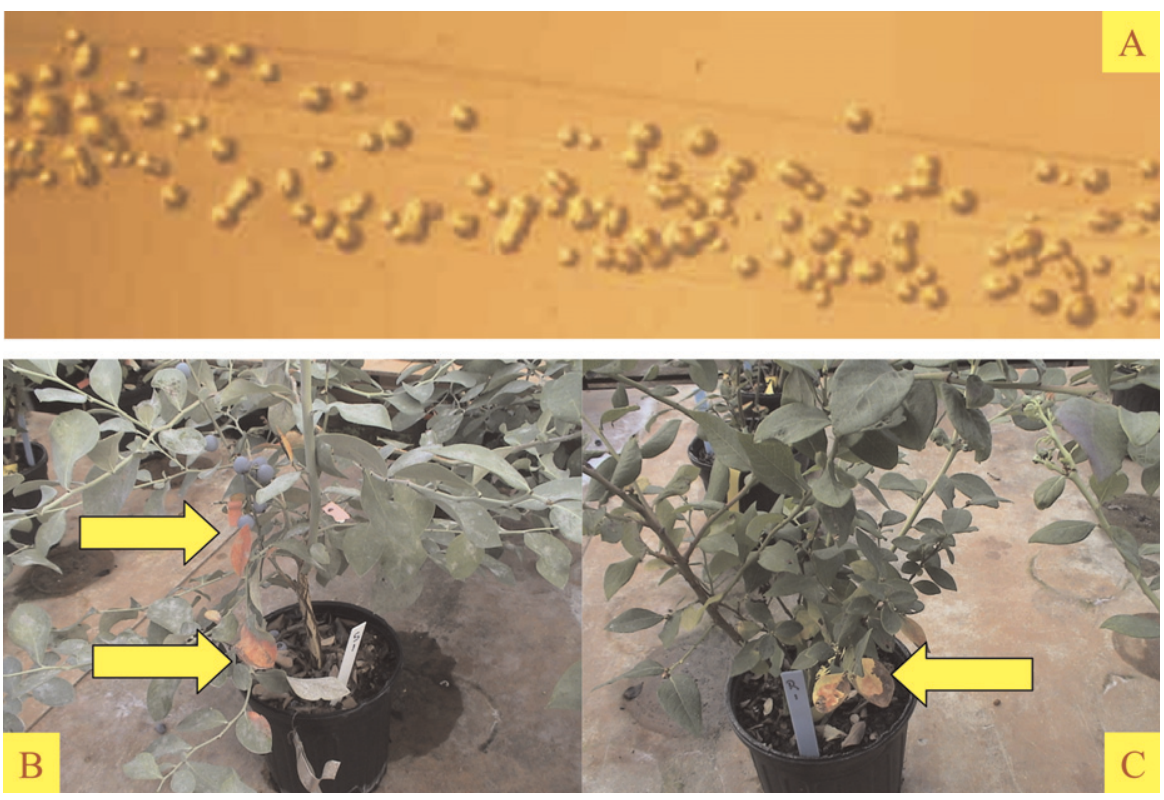

Fig. 1. (A) Colonies (40x) of 14-d-old X. fastidiosa strain on XF-26 medium isolated from root tissues of a diseased blueberry plant. (B) Symptoms (arrows) on 'Powderblue' injected with a stem-isolated strain (S1) observed 125 d postinoculation. (C) Symptoms (arrow) on 'Southern Belle' injected with a rootisolated strain (R1) observed $125 \mathrm{~d}$ postinoculation.
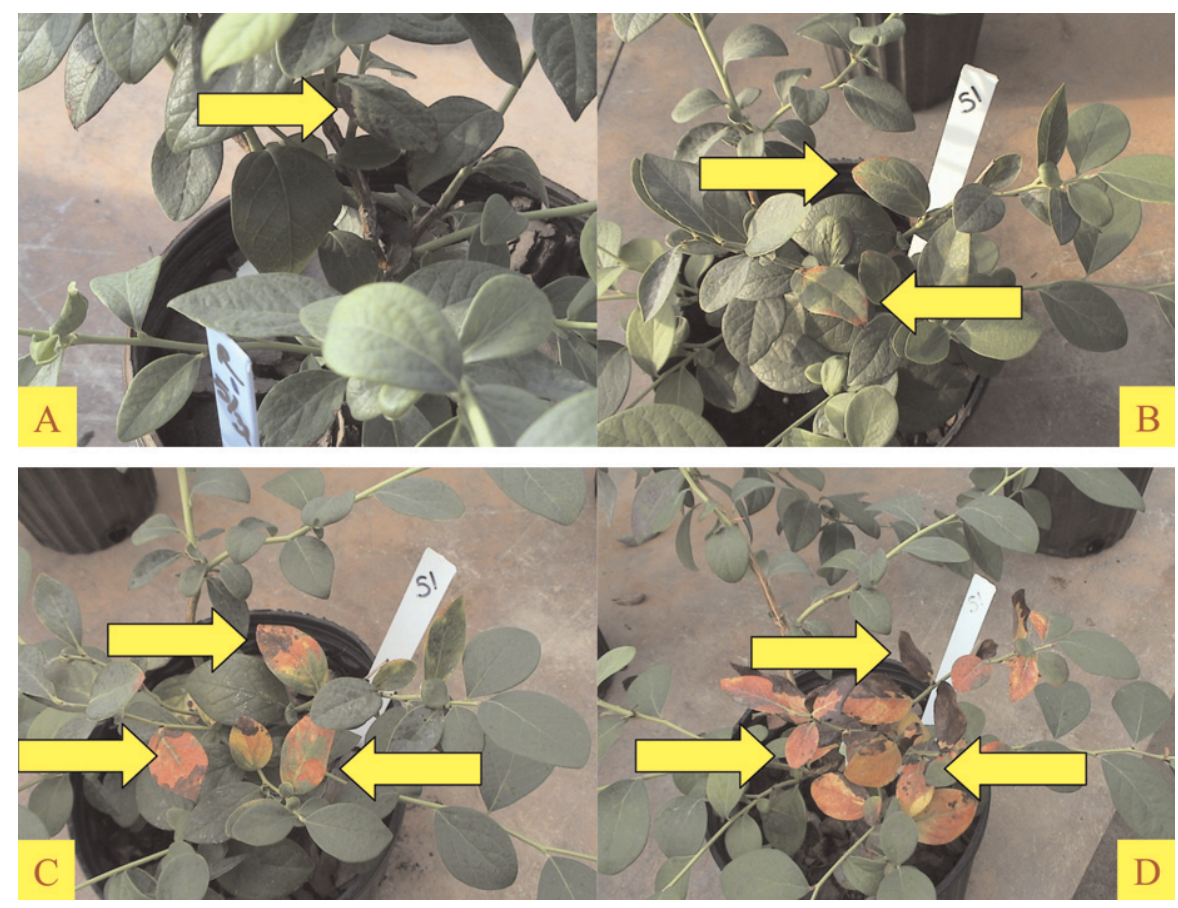

Fig. 2. (A) First leaf marginal necrosis symptom (arrow) developed on selection FL 86-19 injected with a root-isolated strain (R1) $54 \mathrm{~d}$ postinoculation. (B) First leaf marginal discoloration symptoms (arrows) developed on FL 86-19 injected with a stem-isolated strain (S1) 61 d postinoculation. (C) Much degenerated and necrotic symptoms (arrows) on the same FL 86-19 plant shown in B observed 73 d postinoculation. (D) More pronounced symptoms (arrows) on the same FL 86-19 plant shown in B and $\mathbf{C} 105 \mathrm{~d}$ postinoculation.

\section{Direct isolation and enzyme-linked immunosorbent assay test results from inoculated blueberry plants}

Cultivars Premier, Powderblue, and Southern Belle. Four isolations and ELISA tests were performed on various tissues from these plants: one of each test on Days 36, 71, lation and ELISA results were negative for 'Premier', one of six (17\%) was positive for both isolation and ELISA in 'Powderblue' and two of eight $(25 \%)$ were positive for isolation and one of eight $(12.5 \%)$ was positive for ELISA for 'Southern Belle'. The fourth isolation and ELISA were carried out $142 \mathrm{~d}$ postinoculation and the tissues used were random leaves beyond leaf 9. The results were as follows: negative in both isolation and ELISA for 'Premier', negative in isolation and one of six (17\%) in ELISA was positive for 'Powderblue', and one of eight $(12.5 \%)$ in isolation and four of eight $(50 \%)$ in ELISA were positive for 'Southern Belle'.

Selection FL 86-19. The results of the four isolations and ELISA tests (Table 2) clearly show that the bacterium moved rapidly in tissues of selection FL 86-19. For instance, $41 \mathrm{~d}$ after the initial inoculation, when leaves 1,3 , and 5 above the inoculation site were tested, seven of eight $(87.5 \%)$ were positive for bacterial isolation and four of eight $(50 \%)$ were positive in ELISA tests for $X$. fastidiosa (Table 2). The bacterium was detected 13 $\mathrm{d}$ before the first symptoms were recorded. The remaining three isolations and ELISA test sampling dates using leaves further away from the inoculation site showed a consistently high percentage recovery of the bacterium in isolation $(62.5 \%$ to $75 \%)$ and in ELISA $(62.5 \%$ to $87.5 \%$ ) (Table 2$)$. Given the fulfillment of the Koch's postulates, we can now add "bacterial leaf scorch of blueberry" to the lists of blueberry diseases and $X$. fastidiosa-induced diseases.

\section{Discussion}

In addition to the similarity of the colony sizes and morphology between $X$. fastidiosa of oak leaf scorch (Chang and Walker, 1988) and that isolated from the yellow twigs or yellow stems of affected blueberry plants, the ELISA results provide strong evidence that $X$. fastidiosa is directly related to the yellow twigs or yellow stems of blueberry. This contention is supported by the fact that the ELISA kit manufactured by Agdia, Inc. has been widely used for the detection of $X$. fastidiosa in a wide range of hosts (Sherald and Lei, 1991). The Agdia ELISA kit has been widely used for the detection of $X$. fastidiosa in general because the kit gives no cross-reaction to its closest relatives, Xanthomonas spp. (Wells et al., 1987).

Another interesting finding was that the blueberry strains grew well on the chemically defined medium XF-26, which was developed only for the support of the growth of PD strains (Chang and Donaldson, 1993). The 16S-23S rDNA internal transcribed spacer sequencing was conducted for two strains (one stem strain and one root strain from the same diseased plant) of blueberry $X$. fastidiosa recently. A BLAST search (Altschul et al., 1990) of two sequences indicated that the two blueberry strains are $99 \%$ similarity to the M12 strain of almond leaf scorch $X$. fastidiosa (C.J. Chang, unpublished data). The 


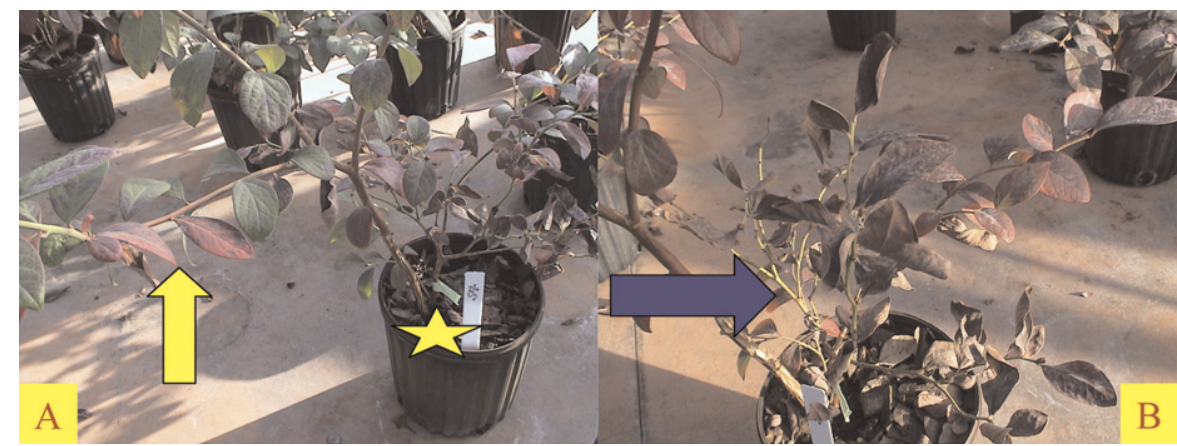

Fig. 3. (A) Symptoms (arrow) on FL 86-19 with necrotic and discolored tissues on leaves appeared on branches that were not injected 153 d postinoculation. Note the branch with a green tape (star) was injected with a stem strain. (B) Symptoms (arrow) of yellow stems and severe necrotic and degenerated leaves were recorded on FL 86-19 plant injected with a stem strain 190 d postinoculation.

genetic relationship among the blueberry strains, the PD strains, and the almond leaf scorch strains warrants further investigation.

Symptoms of marginal necrosis began to develop on the original diseased blueberry bush $\approx 5$ months after it was moved from the cold room to the greenhouse and by 6 months, symptoms were observed on all new growth. Unfortunately, the original blueberry bush died $\approx 24$ Oct. 2006, less than 9 months after excavation. This original blueberry bush provided valuable information on the survivability of the $X$. fastidiosa blueberry strain. The bacterium was able to survive at $5{ }^{\circ} \mathrm{C}$ for 48 $\mathrm{d}$ when the bush was kept in a plastic bag before being planted in a large pot and kept in the greenhouse. On 10 July 2006, tissues from this bush were collected for isolation and ELISA as described previously; the results were positive for both methods. The blueberry industry - particularly growersin the southeastern United States will find this information especially important, because the research suggests that the bacteria is able to survive in aboveground tissues through the south Georgia winter because it is unlikely for the temperature to remain at $5{ }^{\circ} \mathrm{C} 24 \mathrm{~h}$ a day for a consecutive $48 \mathrm{~d}$ in the winter. Furthermore, the source of inoculum for transmission would likely be available yearround. Additional research is necessary to confirm this preliminary observation on survivability, because no repeat of the same cold treatment was conducted for this project.

By 3 months after initial inoculation, all eight $X$. fastidiosa-injected FL 86-19 plants showed symptoms, whereas all four PW medium-only-injected plants remained asymptomatic. For the other three cultivars, only two of six 'Powderblue' and four of eight 'Southern
Belle' showed mild symptoms, whereas zero of six 'Premier' plants were symptomatic even at 4 months postinoculation. Both ELISA and direct isolations confirmed the presence of $X$. fastidiosa in symptomatic plants. Yellow stems or twigs were a strong symptomatic indicator of $X$. fastidiosa infection. There seemed to be a different degree of susceptibility among the three cultivars and one selection with selection FL 86-19 clearly being the most susceptible consistent with what had been previously observed in the field. More work, including repeating the comparison of the previously mentioned three cultivars plus other cultivars and selection FL 86-19, is necessary before a cultivar is considered resistant or tolerant to blueberry $X$. fastidiosa. In 2007, blueberry $X$. fastidiosa was isolated from the following three diseased rabbiteye blueberry cultivars, Star, Palmetto, Ochlockonee, and one southern highbush Millennia (C.J. Chang, unpublished data). In the past 2 years, $X$. fastidios has become a major disease of southern highbush blueberries in Georgia and Florida (Brannen et al., 2007). Given these findings, it is critical that the blueberry industry begins regular screening for cultivars that are resistant or tolerant to $X$. fastidiosa.

\section{Literature Cited}

Almeida, R.P.P., C. Wistrom, B.L. Hill, J. Hashim, and A.H. Purcell. 2005. Vectors transmission of Xylella fastidiosa to dormant grape. Plant Dis. 89:419-424.

Altschul, S.F., W. Gish, W. Miller, E.W. Myers, and D.J. Lipman. 1990. Basic local alignment search tool. J. Mol. Biol. 215:403-410.

Baumgartner, K. and J.G. Warren. 2005. Persistence of Xylella fastidiosa in riparian hosts near northern California vineyards. Plant Dis. 89: 1097-1102.
Brannen, P., G. Krewer, B. Boland, D. Horton, and C.J. Chang. 2007. Bacterial leaf scorch of blueberry. 7 Nov. 2007. <http://www.smallfruits.org/ blueberries/pestinformation/2007/blueberryxylel la.pdf $>$.

Chang, C.J. and R.C. Donaldson. 1993. Xylella fastidiosa: Cultivation in chemically defined medium. Phytopathology 83:192-194.

Chang, C.J. and T.J. Walker. 1988. Bacterial leaf scorch of northern red oak: Isolation, cultivation, and pathogenicity of xylem-limited bacterium. Plant Dis. 72:730-733.

Chang, C.J. and B. Zheng. 1999. Isolation of Spiroplasma citri from flowers and seeds collected from infected periwinkles. Plant Dis. 83:60-61.

Davis, M.J., W.J. French, and N.W. Schaad. 1981. Axenic culture of the bacteria associated with phony disease of peach and plum leaf scald. Curr. Microbiol. 6:309-314.

Feeley, J.C., R.J. Gibson, G.W. Gorman, N.C. Langford, J.K. Rasheed, D.C. Mackel, and W.B. Baine. 1979. Charcoal-yeast extract agar: Primary isolation medium for Legionella pneumophila. J. Clin. Microbiol. 10:437-441.

Hernandez-Martinez, R., K.A. de la Cerda, H.S. Costa, D.A. Cooksey, and F.P. Wong. 2007. Phylogenetic relationships of Xylella fastidiosa strains isolated from landscape ornamentals in southern California. Phytopathology 97:857864.

Montero-Astua, M., G. Saborio-R., C. ChaconDiaz, L. Garita, W. Villalobos, L. Moreira, J.S. Hartung, and C. Rivera. 2008. First report of Xylella fastidiosa in avocado in Costa Rica. Plant Dis. 92:175.

Myers, A.L., T.B. Sutton, J.A. Abad, and G.G. Kennedy. 2007. Pierce's disease of grapevines: Identification of the primary vectors in North Carolina. Phytopathology 97:1440-1450.

Raju, B.C., J.M. Wells, G. Nyland, R.H. Brlansky, and S.K. Lowe. 1982. Plum leaf scald: Isolation, culture, and pathogenicity of the causal agent. Phytopathology 72:1460-1466.

Randall, J.J., M. Radionenko, J.M. French, M.W. Olsen, N.P. Goldberg, and S.F. Hanson. 2007. Xylella fastidiosa detected in New Mexico in chitalpa, a common landscape ornamental plant. Plant Dis. 91:329.

Sanderlin, R.S. and K.I. Heyderick-Alger. 2000. Evidence that Xylella fastidiosa can cause leaf scorch disease of pecan. Plant Dis. 84:1282-1286.

Scherm, H. and G. Krewer. 2003. Blueberry production in Georgia: Historical overview and recent trends. Small Fruits Rev. 2:83-91.

Sherald, J.L. and J.D. Lei. 1991. Evaluation of a rapid ELISA test kit for detection of Xylella fastidiosa in landscape trees. Plant Dis. 75: 200-203.

Wells, J.M., B.C. Raju, H.-Y. Hung, W.G. Weisburg, L. Mandelco-Paul, and D.J. Brenner. 1987. Xylella fastidiosa gen. nov., sp. nov: Gram-negative xylem-limited, fastidious plant bacteria related to Xanthomonas spp. Intl. J. Syst. Bacteriol. 36:136-143. 